\title{
Censorship, Shame and Pornography in East-European (Post-World War II) Literature ${ }^{1}$
}

\author{
CAMELIA TEODORA BUNEA
}

\begin{abstract}
The aim of this paper is to closely follow the dynamics of concepts such as shame or pornography as seen throughout the lens of East-European (post-World War II) literature focusing only on the books that had the power and courage to change the perspective or the whole definition(s) of this terms. Moreover, I want to show if/how the Communist Regime changed the perception, the mentality or, with Pierre Bourdieu's term, habitus of some countries and if/ how is the change reflected in literature focusing my research mostly on Romanian, (but also Polish and Hungarian) prose which means I will also try and understand and explain the dynamics of another concept - censorship. What did censorship meant before, how was it seen after the Regime was installed - from a writer's point of view, of course - and, more important, how people's perspective(s) were changed regarding subjects such as intimacy, sexuality and literature.
\end{abstract}

Keywords: East-European literature; habitus; censorship; pornography

Taking into consideration that the studies about censorship written in the last years where conventional approaches on the subject of censorship reflected in the concentrated analysis of institutional prohibiting acts while a more sophisticated or subtle understanding of censorship was put aside, I wanted to follow a different path using an approach similar to what Reinhart Koselleck did in his study The Practice of Conceptual History. Koselleck's perspective was to reconsider important texts in terms of socio-cultural and political relevance with the sole purpose of isolating within their cores fundamental concepts encompassing (subjective) historical truths of some experiences which changed over time following a complex social dynamics (that was not always linear). Based on a comparative approach, Koselleck's analysis leaves behind the event-based perspective of historians, relying more on the creative power of language through acquisition while following the dynamics in the field of semantic concepts such as culture, progress, utopia, enemy, revolution and so on.

1 This work was supported by a grant of the Romanian National Authority for Scientific Research and Innovation, CNCS- UEFISCDI, project number PN-II-RUTE-2014-4-0240. 
Censorship, Shame and Pornography in East-European (Post-World War II) Literature

Thus, I will replicate his approach by following the dynamics in the field of some other semantic concepts important to our subject - censorship, pornography and habitus - trying to see how these concepts changed in East and Central Europe focusing more on the Romanian prose and how the literary discourse can reflect sometimes more subtly, some other times more directly, and these cultural changes.

\section{Censorship and some misconceptions}

Firstly, we should take into account the dynamic of the term censorship that reinvented itself throughout history finding its place in every age (and geographical area) - as emphasized by Pierre Bourdieu in his book Language and Symbolic Power where he proposes the hypothesis that censorship could be an unavoidable structural necessity: be it internal or external: "The censorship exercised by the structure of the field determines the form [...] and, necessarily, the content, which is inseparable from its appropriate expression and therefore literally unthinkable outside of the known forms and recognised norms." (Bourdieu 1991: 139)

Michel Foucault's influence on the subject should not be minimized, because in The History of Sexuality, he manages to refute the theory which stated that the nineteenth century was an era of shame, modesty and sexual repression. Historians fail to understand, in Foucault's view, the paradoxical power of censorship, arguing that sex should be the part of an obsessive attention during exact this period. And this excessive interest around what seemed a hotbed of cultural anxiety actually led to the development of the "area" of sexuality rather than exclude it from discourse. This assumption results in the reconfiguration of the concept of (self) censorship, while realizing that censorship had the power to both help build a discourse of sexuality but also setting its limits.

All these approaches lead us to conclude that censorship, in either internal or external form, should be accepted as a truly ubiquitous reality, while awareness and acceptance of its creative / productive side results in an entirely different discussion.

In an article published recently in the Australian Humanities Review, Nicole Moore points out the fundamental difference of perception and definition of censorship arguing that, in terms of the geography and national history, the subject may be seen quite differently. She states that

Soviet-style socialist cultural regimes not only differed from each other, but were qualitatively different from Western-style regulatory censorship, in their aims, effects and application. Those forms of cultural dictatorship continue 
BUNEA

to be seen in the West as always already retrograde, construed as socially conservative because most Western censorship is. (Moore, 2013: 54)

Nicole Moore feels the need to stress the importance of contextualization - seen as focusing on the space and political regime of the chosen geographical area so as to be able to answer the question "What is censorship?". Identifying the mechanisms of censorship in every single society proves also to be an attempt to identify the limits and the effects of regulation as such. Censorship is still deeply rooted, its understanding depending on the temporal and spatial features of the regimes where censorship developed its numerous facets.

Therefore, we can make a simplistic observation that between the perspective of Central and Eastern Europe and the Western perspective, there is certainly a gap. In the West, where censorship has developed on a slightly different sociocultural and political pattern, the idea of the creative power of speech which lies inside censorship's regulations may be acceptable with more openness and objectivity.

\section{Theories concerning the concept of habitus: from Norbert Elias' civilizing process to Cas Wouters' third nature}

Secondly, I felt the need to closely follow the dynamics of the term habitus which is a concept well known nowadays especially due to Pierre Bourdieu's works, but having in mind that Norbert Elias was clearly among the first sociologists who have stressed the importance of the set of customs and traditions of behavior. Norbert Elias created a theory that should be nowadays accepted as playing a vital part in understanding any social process as such, making sense of human behavior and the ways in which societies develop and interconnect:

Elias traces what he believes is a long-term process (not without reversals) of increasing pacification and self-control within Europe since the early Middle Ages. This civilizing process has a paradoxical effect. It increases human interconnectedness but at the same time increases people's feelings of being isolated from each other. The civilizing process gives modern men and women the capacity to have a detached attitude towards themselves and their relationships with others. It also tends to make them very inhibited. (Smith 2001:149)

Cas Wouters, a contemporary Dutch sociologist, is best known for further developing Elias' theory of the process of civilization. What Wouters did was to analyze the Dutch society of the 1960 s and 1970 s stressing out the fact that 
this period enables a major change in behavioral codes (of the Dutch) - a greater openness to everything new, an increased level of permissiveness: especially in the field of sexuality and that of the external look. Everything changes in the Dutch society between the 1960s and the 1970s, the behavior becoming increasingly less rigid, more informal in terms of clothes, music, dance and so on - what he called the process of informalization.

Further building on the basis of Elias' theory, Cas Wouters creates this concept of the process of informalization describing it as forming part of the civilizing process, arguing that this has an opposite twin, the process of formalization. The tendency towards informalization started to diminish gradually until the 1980s when social behaviors begun to formalize again: the informalization process gradually saw a regression towards old customs combined with the new ones, but containing a higher degree of rigidity, formality and control over social behavior. What changed was, as Wouters suggested, an increase in expectations regarding self-constraints - mutually expected self-restraints - a mutual expectancy from themselves and from each other about the fact that individuals should not longer have to censor feelings and behavior under the old formal models, but subtly adapt to the environment changing the models according to the situation and the relationships involved: a controlled decontrolling of emotional control. ${ }^{2}$

In fewer words, Cas Wouters introduces a new consciousness and a new form of self-regulatory behavior more reflective and more flexible than that of Elias which operated automatically, instinctively. This is actually Wouters's concept of the third nature representing a higher level of awareness and self-analysis by taking into account all types of constraints and possibilities of reaction. Elias's habitus transforms over time in a kind of emotionally controlled habitus that incorporates a certain degree of autonomy - the capacity acquired in time to partly isolate from the external influence by creating their own criteria for assessment. This kind of habitus is born, grows, changes, dims and may disappear in time.

\section{Life reflected in East-European literature: from trials of morality to the rising of the concept of pornography}

If we are to take a closer look at our literary tradition, Romanian eroticism was indeed a byproduct of modernization, as Virgil Candea has suggested (Candea 1972: XV). As Andrei Bodiu wrote (2002: 15-16), the Romanian prose written after 1860 suffers a double mutation: an adaptation of the popular writers,

2 Cas Wouters developed the concepts of formalization, informalization and the third nature in Wouters 2009. 
BUNEA

especially French because that was the place where the influence emerged back then, autochthonization of the action and the theme which was, at the time, love and lovemaking. But, as High Romanticism came to an end, the passionate, allconsuming love came to be crushed by some writers who felt the need to reflect the reality of the time in their short stories or novels. The readers of these stories come across infidelity and treason while dramatic subjects such as suicide were treated with subtle irony and most of the situations seem to be more comic than tragic. Thereby, Romanian literature was accused of immorality and obscenity, long time before the era of totalitarianism which is a clear sign of the existence of social censorship governed by the culture of the time, and traditional religiousbased unwritten rules.

Some of the Romanian prose written around 1860 s may very well reflect what Norbert Elias understood by breaking the shame threshold. One of the first steps of what Cas Wouters referred to as the informalization process inside the Romanian culture was accepting some mildly suggested erotic scenes.

There are plenty of examples to deal with, but one of the most well known implies a trial where a teacher and writer named Bogdan P. Hașdeu was accused of immorality in 1863 for his novella in which he described with fabulous irony and humour the market of infidelity and private life's subtleties and details. But this was one isolated case of overflowing literary intimacy until later on - between wars - when the rebellious spirit of the avant-garde emerged and many other pornography trials and even actual convictions appeared. Geo Bogza was one of a series of writers that was convicted for his poetry volume called Jurnal de sex (The Diary of Sex, 1929) with explicit sexual content.

The purpose of these writings was the purge of the fake bashfulness of the literary discourse which was hypocritical in contrast with the way of life.

Gradually, another break in the shame threshold started to take shape. Nowadays the moment is easily recognized when talking about the discourse of sexuality inside Romanian prose: 1933, a year when a lot of the published novels forced taboos firstly at the level of non-sexual bodily speech, but also at the level of sexual discourse: Hortensia Papadat Bengescu's characters develop long passages about body, disease (something that Max Blecher did even better) and desire. Characters seem to have earned their flesh and talk about the inadequacy between one's body and one's sensitivity which end up being in a divergent relationship. Naturally, her novels were not well received by critics. As Simona Sora states in her book Regăsirea intimității (The Retrieval of Intimacy, 2008), their problem was actually accepting the new aesthetic of corporality filtered by the uninhibited life of the 1920s.

There was even an interesting article in 1934 in a Romanian journal ironically called Books make it to index listing the "soiled by malediction" volumes which 
Censorship, Shame and Pornography in East-European (Post-World War II) Literature

were actually most of the books published around the year when the piece was printed.

Going further than Hortensia Papadat Bengescu, Mircea Eliade expands the vision about body and sexuality by expanding the borders of the subject, the bodies and desires of his characters being always ambivalent-mystical and modern, pure and depraved, sensual and shy.

It is needless to say that, between 1950 and 1989 - as of course happened between 1860 and 1933 - there were few writers who gradually, at some discursive level and making use of creative (narrative) subterfuges, changed the discourse of sexuality inside our culture. Authors such as Eugen Barbu, Nicolae Breban, Augustin Buzura, Radu Petrescu, Gabriela Adameșteanu or Gheorghe Crăciun had a saying inside the rule-changing censored culture of Stalinism and National communism.

A period of relaxation was brought by the 1960s even though no real political liberalization took place and no retreat from the fundamentals of the Stalinist economic model were to be found, but the intrusiveness of the regime in individual lives was mildly decreasing. But the calm and the lack of intrusion did not last. At the beginning of the 1970s the regime started to be more and more focused on limitations and rules. Literary censorship begun to indulge less and less discourses or subjects matters or names of the characters until even words like bed or sleep were sometimes avoided. Mostly everything that seemed to point out to sex and sexuality was labeled as having pornographic connotation(s).

Inside this very strict and paranoid literary and cultural context writers tried to keep their individuality intact and focus their writings on authenticity. I think here is one of the main differences between West and East and Central Europe. While the West came to liberate themselves out of the social or religious constraints (Americans or the Dutch ) and learned on their own what limitless freedom can do, people inside totalitarian regimes develop a sort of artificial third nature not because they were faced with the consequences of what Kundera called the unbearable lightness of being, but mostly because of the need to shield external intrusion and keep their own individualities as intact as they could. For Romanian writers, the 1970s and 1980s had more to do with defending the right to be oneself, with the preserving of authenticity and creativity more than the focus on sexual liberation. It is true thought that the beat generation influenced our poets of the 1980s, but prose was more focused on fighting the censorship limitations, on staying truthful and trying to maintain the literary discourse at a certain intellectual value while being able to be published.

Compared with the Romanian political background, Hungarian writers were a bit more lucky in terms of political censorship. Peter Esterhazy's novel called $A$ little Hungarian Pornography was published in 1983 even if the author makes use 
BUNEA

of pornography as a metaphor for a rapid surrendering and becoming complicit in oppression. A multitude of degraded feminine bodies occur frequently as Esterhazy plays with the languages of power and freedom (sexuality and relief from the lies of words).

Another contrasting example is the publishing of the novella called Love by Peter Nadas, even earlier, in 1979: the hallucinatory, unforgettable story filled with lust and betrayal in an uncertain love affair. It is a story that seems to have no plot. It is exploring several bodily desires. It happens around a bed. It implies sexuality. It is a story about a lover who has actually come to tell his married mistress that he wants to leave her, but as soon as he sees her he realizes he won't be able to break up. While the woman rolls a joint he already drifts into another state of mind questioning himself about life and love and death, all subjects and plots that Romanian writers wouldn't even be permitted to think about, nonetheless write about in that exact period of time.

After 1989, there was a sort of erotic outbreak in both Romanian literature and mass media, a false impression of regaining intimacy throughout a wave of very direct and sometimes totally non-erotic language, more denotative than connotative. This first decade of the 1990s is maybe, in my opinion, the period where a more similar type of emotionally controlled habitus started to develop in Romania because, exactly like the Dutch, when confronted with the lack of meaning or purpose (aesthetic or ethical), important and valuable writers started to back down gradually and to mutually ask for more behavioral self-restraining including the choice of their subject and language when writing about love or intimacy. Like American Psycho where Bret Easton Ellis depicted everything that he found atrocious, vulgar, degrading and infamous in the 1980s and then the scene sort of quiets down. Somehow a similar mutations happens in our literature, too. The scene sort of quiets down, novels leaving behind the licentious language letting it finding shelter just in the stories where it has an (aesthetic or ethical) purpose.

\author{
Camelia Teodora Bunea \\ bunea.camelia@fundatiamicubogdan.ro \\ Nr. 66, Garii Street \\ Ianca, Braila County 815200 \\ ROMÂNIA / ROMANIA
}


Censorship, Shame and Pornography in East-European (Post-World War II) Literature

\section{Bibliography}

Bodiu, A. 2002. Șapte teme ale romanului porstpașoptist. Pitești: Paralela 45.

Bourdieu, P. 1991. Language and Symbolic Power. Ed. by J. B. Thompson, transl. by G. Raymond and M. Adamson. Oxford: Polity Press.

Candea, V . 1972. Introducere. - D. de Rougemont, Iubirea și Occidentul. București: Univers, $\mathrm{v}-\mathrm{xv}$.

Koselleck, R. 2002. The Practice of Conceptual History. Timing History, Spacing Concepts. Transl. by T. Presner, K. Behnke, J. Welge. Stanford: Stanford Univesity Press.

Moore, N. 2013. Censorhsip Is. - Australian Humanities Review, 54, 40-65 that can be found at the following address http://www.australianhumanitiesreview.org/ archive/Issue-May-2013/moore.html (10.07.2016)

Smith, D. 2001. Norbert Elias and Modern Social Theory. London: SAGE Publications Ltd. Sora, S. 2008. Regăsirea intimității. București: Cartea Românească.

Wouters, C. 2009. The Civilizing of Emotions: Formalization and Informalization. D. Hopkins, J. Kleres, H. Flam, H. Kuzmics, eds., Theorizing Emotions: Sociological Explorations and Applications. New York \& Frankfurt am Main: Campus Verlag, 69-194. 